\title{
Kecerdasan Interpersonal Siswa Kelas 1 MI dalam Model Pembelajaran Menyimak Tipe Bisik Berantai Mata Pelajaran Bahasa Indonesia
}

\author{
Muhammad Majdi ${ }^{1}$, Ahmad Shofiyuddin Ichsan ${ }^{2^{*}}$ \\ ${ }^{1}$ Sekolah Tinggi IImu Al-Quran Amuntai, ${ }^{2}$ Insitut IImu AI Qur'an An Nur Yogyakarta \\ 1 muhammadmajdi755@gmail.com, ${ }^{2^{*}}$ ahmad.shofiyuddin.ichsan@gmail.com
}

\section{Abstrak}

Penelitian bertujuan untuk memahami model pembelajaran menyimak tipe bisik berantai dan hubungannya dengan kecerdasan interpersonal siswa kelas 1D Madrasah Ibtidaiyah (MI) Plus Al Hamid Banjarmasin. Model pembelajaran menyimak tipe bisik berantai adalah permainan yang dapat mengembangkan aspek-aspek kebahasaan, mendengar, berbicara, menulis, dan membaca. Penelitian ini menggunakan penelitian kualitatif dengan tipe induktif. Subjek penelitian ini adalah wali kelas ID dan 29 siswa kelas I D program Tahfid. Hasil dari penelitian ini adalah implementasi model pembelajaran menyimak tipe bisik berantai yang dilakukan guru kelas 1D MI Al Hamid Banjarmasin berjalan dengan baik. Mereka juga menambahkan variasi mengajar untuk menunjang pembelajaran yang efektif dan tepat sasaran. Dalam konteks kecerdasan interpersonal, maka dapat dipahami sesuai dengan indikatornya adalah siswa mampu untuk: 1). Berkomunikasi verbal dan nonverbal serta mampu berinteraksi aktif dengan teman sebaya, guru maupun civitas akademika (sekolah). 2). Menjadi penengah dalam kelompok di sekitarnya dan memiliki keahlian untuk bekerja dalam kelompok, 3). Mengenali berbagai cara untuk berhubungan dengan orang lain dan peka terhadap perasaan, motivasi, dan keadaan mental seseorang, 4). Membentuk dan mempertahankan suatu hubungan sosial, dan 5). Mudah bergaul serta dapat beradaptasi dengan lingkungan pergaulan dengan baik.

Kata Kunci: Kecerdasan Interpersonal, Model Pembelajaran Menyimak Tipe Bisik Berantai

\section{Pendahuluan}

Bidang studi yang diajarkan di Sekolah Dasar salah satunya adalah mata pelajaran Bahasa Indonesia. Mata pelajaran Bahasa Indonesia di Sekolah Dasar merupakan mata pelajaran strategis karena dengan berbahasa, pendidik dapat menularkan ilmu pengetahuan dan pengalaman kepada siswa. Sebaliknya, dengan berbahasa pula, siswa dan pendidik akan saling bertukar informasi satu sama lain, sehingga terjadi proses pembelajaran yang konstruktif dan efektif di ruang lingkup pendidikan.

Dalam kaitannya dengan tujuan pembelajaran Bahasa Indonesia, terdapat konsep keterampilan yang bisa dijelaskan, yakni membaca, menulis, berdialog, dan menyimak. Keterampilan menyimak adalah saran membina siswa agar bisa menceritakan kembali apa yang didengarnya, menjawab pertanyaan dari kalimat/cerita yang didengarnya, menarik kesimpulan, menemukan kosa kata baru, mengingat fakta-fakta (seperti nama orang, tempat, mengurutkan kejadian, dan seterusnya), dan meningkatkan pemusatan perhatian (seperti kemampuan mendengarkan perintah, menjelaskan maksud dan mengurutkan kata-kata menjadi kalimat, dan seterusnya). 
Dalam Kamus Besar Bahasa Indonesia, Djago Tarigan mengatakan bahwa "Mendengar diartikan sebagai menangkap bunyi (suara) dengan telinga. Mendengarkan berarti mendengarkan sesuatu dengan sungguh-sungguh. Sedangkan menyimak berarti mendengarkan (memperhatikan) baik-baik apa yang diucapkan atau dibaca orang". Uraian di atas dapat dipahami menjadi pengertian atau definisi sebagai berikut: menyimak adalah suatu proses yang mencakup kegiatan mendengar, mengidentifikasi, menginterpretasi bunyi bahasa kemudian menilai hasil interpretasi makna dan menanggapi pesan yang tersirat di dalam wahana bahasa tersebut. Dalam bahasa yang mudah dan sederhana, menyimak berarti kemampuan memahami pesan yang disampaikan melalui bahasa lisan (Tarigan, 2003:25). Maka keterampilan menyimak adalah satu bentuk keterampilan berbahasa yang bersifat reseptif. Dalam proses pembelajaran, keterampilan akan mendominasi aktivitas seseorang dibanding keterampilan lainnya, termasuk keterampilan berbicara (Iskandarwassid, 2011:227).

Dalam permainan berbicara, terdapat permainan bisik berantai yang menurut Suyatno bertujuan "agar siswa dapat memahami informasi yang dibisikkan oleh temannya dengan cermat, cepat, dan tepat. Siswa dalam hal ini mendengarkan informasi yang telah diutarakan oleh temannya, kemudian menyampaikannya ke teman yang ada di sebelahnya secara berantai dalam satu kelompok" (Suyatno, 2004:128). Adapun langkah-langkah dari permainan bisik berantai dapat dijelaskan sebagaimana berikut: 1). Guru membisikkan suatu pesan kepada seorang siswa, 2). Siswa tersebut membisikkan pesan itu kepada siswa kedua, ketiga dan seterusnya, 3). Siswa terakhir menyebutkan pesan itu dengan suara jelas di depan kelas, dan 4). Guru mengevaluasi hasil dari pesan yang disampaikan siswa (Asih, 2016:147).

Dilihat dari langkah-langkahnya di atas, permainan bisik berantai merupakan permainan yang dapat mengembangkan aspek-aspek kebahasaan, di antaranya adalah menyimak/mendengar, berbicara, menulis, dan membaca. Maka dari itu, permainan bisik berantai ini dapat dipergunakan dalam proses pembelajaran, baik di kelas maupun di luar kelas, karena hal tersebut sesuai dengan tingkat perkembangan anak Sekolah Dasar (SD) / Madrasah Ibtidaiyah (MI) yang masih cenderung senang bermain. Dengan strategi bermain, siswa dapat menikmati pembelajaran dengan senang, sehingga hasil yang didapatkan dapat optimal (Kholifatun, 2018:4).

Permainan bisik berantai (yang menekankan pada aspek kebahasaan dengan proses permainan yang menggembirakan) memiliki hubungan erat dengan kecerdasan interpersonal seseorang. Sebagaimana yang jelaskan oleh Thomas Armstrong, kecerdasan interpersonal merupakan kemampuan mempersepsi dan membedakan suasana hati, maksud, motivasi, serta perasaan orang lain. Kecerdasan ini meliputi: 1). Kepekaan pada ekspresi wajah, suara, gerakisyarat, 2). Kemampuan membedakan berbagai macam tanda interpersonal, dan 3). Kemampuan menanggapi secara efektif tanda tersebut dengan tindakan pragmatis tertentu, misalnya mempengaruhi sekelompok orang untuk melakukan tindakan tertentu. Selain itu Armstrong juga memberikan ciri untuk penilaian kepada siswa yang memiliki kecerdasan interpersonal, antara lain: suka bersosialisasi dengan teman sebaya, berbakat menjadi pemimpin, memberikan saran kepada teman yang mempunyai masalah, mudah bergaul, menjadi anggota kelompok informal di antara teman sebaya, senang mengajari anak-anak lain secara informal, suka bermain dengan teman sebaya, mempunyai dua atau lebih teman dekat, memiliki empati yang baik atau perhatian kepada orang lain, dan banyak disukai teman (Amstrong, 2014:4).

Gardner dan Checkkley dalam Muhamad Yaumi memberikan pengertian kecerdasan interpersonal merupakan kemampuan memahami pikiran, sikap, dan perilaku orang lain. 
Kecerdasan ini merupakan kecerdasan dengan indikator-indikator menyenangkan bagi orang lain. Sikap-sikap yang ditunjukkan oleh anak dalam kecerdasan interpersonal sangat menyejukkan dan penuh kedamaian. Oleh karena itu, kecerdasan interpersonal dapat didefinisikan sebagai kemampuan mempersepsi dan membedakan suasana hati, maksud, motivasi dan keinginan orang lain, serta kemampuan memberikan respons secara tepat terhadap suasana hati, temperamen, motivasi dan keinginan orang lain. Dengan memilki kecerdasan interpersonal, seorang anak dapat merasakan apa yang dirasakan orang lain, menangkap maksud dan motivasi orang lain bertindak sesuatu, serta mampu memberikan tanggapan yang tepat sehingga orang lain merasa nyaman (Yaumi, 2012:21).

Adanya kecerdasan interpersonal, seseorang mampu berhubungan dengan orang-orang di sekitar kita (Lwin, 2008:197). Kecerdasan ini adalah kemampuan untuk memahami dan memperkirakan perasaan, temperamen, suasana, hati, maksud dan keinginan orang lain dan menanggapinya secara layak. Kecerdasan inilah yang memungkinkan kita untuk membangun kedekatan, pengaruh, pimpinan dan membangun hubungan dengan masyarakat. Kecerdasan Interpersonal menunjukan kemampuan seseorang untuk peka terhadap perasaan orang lain. Siswa cenderung untuk memahami dan berinteraksi dengan orang lain sehingga mudah bersosialisasi dengan lingkungan di sekelilingnya. Kecerdasan jenis ini juga sering dikenal sebagai kecerdasan sosial, yakni mampu menjalin persahabatan secara akrab dengan temantemannya, juga mampu memimpin, mengorganisir, menyelesaikan masalah antar teman, dan memperoleh simpati siswa lainnya (Uno, 2010:13).

Kondisi siswa ini sesuai dengan pendapat Adi W. Gunawan mengenai karakteristik siswa yang memiliki kecerdasan interpersonal, yaitu: 1). Membentuk dan mempertahankan suatu hubungan sosial, 2). Mampu berinteraksi dengan orang lain, 3). Mengenali dan menggunakan berbagai cara untuk berhubungan, 4). Mampu mempengaruhi pendapat dan tindakan orang lain, 5). Turut serta dalam upaya bersama dan mengambil berbagai peran yang sesuai, baik menjadi pengikut maupun menjadi pemimpin, 6). Mengamati perasaan, pikiran, motivasi, perilaku dan gaya hidup orang lain, 7). Mengerti dan berkomunikasi dengan efektif, baik dalam bentuk verbal maupun non verbal, 8). Mengembangkan keahlian untuk menjadi penengah dalam suatu konflik dan mampu bekerjasama dengan orang yang mempunyai latar belakang yang beragam, 9). Tertarik menekuni bidang yang berorientasi interpersonal dan menajemen, 10). Peka terhadap perasaan, motivasi, dan keadaan mental seseorang (Gunawan, 2005:118).

Sedangkan menurut T. Safaria karakteristik siswa yang memiliki kecerdasan interpersonal, antara lain: 1). Mampu menciptakan relasi sosial dan mengembangkannya secara efektif, 2). Mampu memiliki empati terhadap orang lain dan memahaminya secara baik, 3). Mampu mempertahankan relasi sosialnya secara efektif dan senantiasa berkembang semakin intim, 4). Mampu menyadari komunikasi verba maupun non-verbal yang dimunculkan orang lain, atau dengan kata lain sensitif terhadap perubahan situasi sosial dan tuntutan-tuntutannya, sehingga anak mampu menyesuaikan dirinya secara efektif dalam segala situasi, 5). Mampu memecahkan masalah yang terjadi dalam relasi sosialnya dengan pendekatan win-win solution, dan mampu mencegah masalah dalam relasi sosialnya, dan 6). Memiliki keterampilan komunikasi dengan cara mendengarkan, berbicara, dan menulis secara efektif (Safaria, 2005:25).

Dari penjelasan di atas, menjadi penting untuk diungkapkan bagaimana permainan bisik berantai mampu memberikan stimulus dalam mengembangkan kecerdasan interpersonal siswa dalam civitas akademika kesehariannya. Akan menjadi menarik jika model pembelajaran menyimak tipe bisik berantai ini dilihat dalam konteks pembahasaan, khususnya dalam Mata 
Pelajaran Bahasa Indonesia. Dengan itu, penelitian ini memberikan manfaat bagi para pendidik, akademisi, dan instansi pendidikan terkait dalam rangka mengaktualisasi proses pembelajaran siswa dengan berbagai model, salah satunya dengan permainan bisik berantai. Penelitian ini juga memberikan gambaran bahwa model pembelajaran menyimak tipe bisik berantai ini dapat dipahami dari sisi kecerdasan interpersonal, sehingga dengan itu akan tercipta suasana pembelajaran yang menyenangkan dengan berdasarkan optimalisasi potensi dari diri siswa itu sendiri.

\section{Metode Penelitian}

Penelitian ini merupakan penelitian kualitatif, yakni menggambarkan keadaan yang ada di lapangan. Adapun pendekatan yang digunakan adalah bersifat induktif. Dalam artian, peneliti membiarkan permasalahan-permasalahan muncul dari data atau dibiarkan terbuka untuk interpretasi. Data dihimpun dengan pengamatan yang seksama, mencakup deskripsi dalam konteks yang mendetil diserta catatan-catatan hasil observasi, wawancara yang mendalam, dan diperkuat dengan dokumentasi lapangan (Sukmadinata. 2015:60).

Oleh karena itu, data yang dikumpulkan berupa kata-kata, gambar dan bukan berupa angka. Subjek dalam penelitian ini adalah wali kelas I dan 29 siswa kelas I D program Tahfid di MI Plus Al-Hamid Banjarmasin. Adapun metode analisis data yang digunakan dalam penelitian ini adalah data kualitatif menurut Cresswell, yakni mengikuti langkah-langkah berikut itu: 1). Mengorganisasi dan menyiapkan data yang akan dianalisa, 2). Membaca, memahami, dan melihat semua data yang masuk terkait model pembelajaran menyimak tipe bisik berantai yang dilakukan siswa di kelas dan hubungannya dengan kecerdasan interpersonal, 3). Membuat koding semua data yang masuk, 4). Menggunakan koding tersebut sebagai bahan dalam membuat deskripsi lanjutan, 5). Menghubungkan antar tema yang terkait, dan 6). Memberikan interpretasi tentang tema dalam penelitian (Sugiyono, 2017:162-163).

\section{Hasil Penelitian \& Pembahasan}

\section{Implementasi Model Pembelajaran Menyimak Tipe Bisik Berantai}

Guru melaksanakan model pembelajaran menyimak tipe bisik berantai pada Mata Pelajaran Bahasa Indonesia dengan tujuan melatih kemampuan menyimak siswa, karena pada kaitannya dengan mata pelajaran lain kemampuan menyimak mempunyai pengaruh yang signifikan. Selain itu penelitian ini mencoba mendeskripsikan pengembangan kecerdasan interpersonal siswa setelah melakukan permainan bisik berantai.

Berdasarkan hasil penelitian yang dilakukan, dapat dipahami bahwa implementasi model pembelajaran menyimak tipe bisik berantai yang telah dilakukan oleh wali kelas 1D yaitu.

\section{Kegiatan Pembuka}

a. Membaca do'a, tepuk semangat, dan bertanya kabar siswa;

b. Apersepsi;

c. Mengkondisikan kelas dengan kalimat-kalimat perintah (seperti istidadan, ijlis, uskut, dan isma);

d. Menjelaskan kegiatan pembelajaran dan tujuan pembelajaran.

\section{Kegiatan Inti}

a. Dari 29 siswa dibagi menjadi 5 kelompok, sedangkan nama kelompok sesuai dengan keinginan siswa. Hal ini bertujuan agar siswa lebih menikmati proses pembelajaran dan lebih semangat untuk mengikuti; 
b. Menjanjikan reward (baik berupa verbal, maupun nonverbal (seperti diberi bintang, dan seterusnya);

c. Guru memainkan permainan bisik berantai beberapa kali putaran sesuai kebutuhan;

d. Setiap kelompok diminta untuk berbaris menjadi 1 berbanjar;

e. Siswa pertama melihat teks atau kalimat sederhana yang ditampilkan oleh guru dan siswa lainnya dalam satu barisan tersebut menghadap membelakangi siswa pertama;

f. Siswa pertama menyampaikan pesan kepada siswa kedua, siswa kedua menyampaikan pesan kepada siswa ketiga dan seterusnya;

g. Siswa terakhir menyebutkan pesan yang disampaikan oleh teman-temannya;

h. Evaluasi bersama.

3. Kegiatan Penutup

a. Guru memberikan apresiasi kepada semua kelompok dengan bertepuk tangan bersama;

b. Guru dan siswa memberikan kesimpulan;

c. Membaca do'a dan salam penutup.

Dapat dipahami dari proses pembelajaran yang dilakukan guru tersebut bahwa hal tersebut dapat melatih kemampuan menyimak dan memberikan stimulus pada kecerdasan interpersonal siswa. Hal ini sebagai hasil wawancara peneliti dengan salah satu wali kelas $1 \mathrm{D}$, sebagaimana di bawah ini.

"Dengan permainan ini, siswa sangat antusias bermain dan tentu seperti ini dapat membantu daya simak siswa untuk terus berkembang. Tujuan yang dicapai siswa dapat berkolaborasi, kooperatif, aktif serta saling membantu dengan temannya serta pada ranah kognitif, afektif dan psikomotoriknya pun berjalan baik. Dari segi kognitif, siswa dapat mengerti kalimat sederhana. Segi afektif, siswa saling membantu, bertanggung jawab, dan saling menghargai dengan teman lainnya. Dari segi Psikomotorik, mereka aktif bergerak di kelas serta dapat menyimak dengan baik. Ini bagi kami bagus untuk terus dilakukan, Mas."

Penjelasan di atas dapat ditarik kesimpulan bahwa model pembelajaran menyimak tipe bisik berantai siswa kelas $1 \mathrm{D}$ MI Al Hamid berjalan baik dibuktikan dengan antusiasnya siswa dalam melakukan permainan tersebut. Tidak hanya itu, model pembelajaran tersebut mampu memberikan banyak manfaat, tidak hanya ranah psikomotoriknya, tetapi juga ranah kognitif dan afektif juga terpenuhi.

Hal ini sesuai dengan apa yang dijelaskan oleh Suyatno. Menurutnya, tujuan dari model pembelajaran permainan bisik berantai ini adalah agar siswa dapat memahami informasi yang dibisikkan oleh temannya dengan cermat, cepat, dan tepat. Dengan permainan bisik berantai, siswa dapat mendengarkan informasi yang disampaikan teman, kemudian menyampaikan informasi yang didengar ke teman sebelahnya secara berantai dalam kelompok (Suyatno, 2004). Maka di sini diperlukan kecermatan, kecepatan, dan ketepatan dalam mendengar serta menjawab apa yang disampaikan oleh temannya. Di titik itulah pengoptimalan proses pembelajaran dapat dipahami secara baik.

\section{Kecerdasan Interpersonal}

Hasil penelitian yang dilakukan peneliti memperlihatkan bahwa secara umum siswa mempunyai kemampuan berkomunikasi cukup baik dalam membangun kerjasama dan hubungan sosial dengan teman kelompok pada langkah kegiatan pembelajaran membisikkan kata. Hal ini sesuai dengan penjelasan Saifuddin Azwar bahwa orang dengan kecerdasan interpersonal adalah mereka yang mampu memperhatikan perbedaan di antara orang lain, dan dengan cermat dapat mengamati temperamen, suasana hati, motif, dan niat mereka (Azwar, 
1996:43). Karena pada dasarnya siswa yang mempunyai kecerdasan interpersonal dapat dipahami dari kemampuannya menjalin komunikasi, mempertahankan hubungan dengan orang lain serta mampu dalam menghadapi serta memahami orang dengan berbagai karakter yang berbeda secara baik.

Secara lebih rinci, di sini peneliti akan menjabarkannya bagaimana kecerdasan interpersonal dapat dipahami sesuai dengan indikator-indikator yang terjadi di lapangan. Adapun indikatornya dijelaskan sebagaimana berikut.

\section{Kemampuan untuk berkomunikasi verbal dan non verbal serta mampu berinteraksi aktif dengan teman sebaya, guru, dan warga sekolah}

Implementasi model pembelajaran menyimak tipe bisik berantai ini memungkinkan siswa untuk berkomunikasi dengan teman kelompoknya agar pesan yang dibisikkan secara berantai itu dapat tersampaikan dengan baik oleh setiap siswa. Terdapat lima kelompok dalam permainan ini, yang mana di dalamnya terdapat berbagai macam karakter siswa. Agar komunikasi dalam kelompok efektif, peran guru sangat berpengaruh dalam mengontrol jalannya permainan. Di dalam kegiatan pembuka, guru menjelaskan beberapa kode permainan, di antaranya: Istidadan untuk siswa agar bersiap-siap, Ijlis untuk meminta siswa duduk, Uskut untuk meminta siswa diam, dan isma' untuk meminta siswa mendengarkan. Jadi pada saat pembelajaran berlangsung untuk meminimalisasi keributan kelas, guru memberikan kode tersebut sesuai yang dikehendaki guru sebagai pengontrol proses pembelajaran.

Dari hasil di lapangan, guru melakukan langkah-langkah yang sangat efektif dalam membuat suasana kelas kondusif. Dengan kondusifitas tersebut, pada akhirnya berdampak kepada komunikasi efektif antar siswa, baik komunikasi verbal maupun non verbal. Maka di sini diperlukan kearifan guru dalam membimbing dan mengontrol berjalannya pembelajaran. Jika guru kurang cermat dalam memahami aturan yang ada, maka dikhawatirkan proses pembelajaran tidak berjalan sesuai harapan, salah satunya akan terjadi kegaduhan di kelas.

Interaksi secara aktif dengan teman sebaya dapat dilihat dari kegiatan kelompok model pembelajaran menyimak tipe bisik berantai ini. Setiap kelompok termotivasi menjadi yang terbaik. Berdasarkan hasil penelitian yang dilakukan oleh peneliti, pada umumnya setiap kelompok terdapat 1-2 siswa yang pasif/pendiam ketika pembelajaran berlangsung, tetapi hal tersebut tidak terjadi ketika guru menggunakan model pembelajaran menyimak tipe bisik berantai ini, karena semua siswa dituntut untuk aktif menjadi satu kesatuan dalam satu kelompok. Keaktifan tersebut dapat dilihat dari saling berkomunikasi dan berinteraksi antar satu siswa dengan siswa lainnya agar hasil yang didapatkan dari permainan tersebut dapat maksimal dan meraih nilai yang baik.

\section{Kemampuan untuk menjadi penengah dalam kelompok dan memiliki keahlian untuk bekerja dalam kelompok}

Pemahaman lain adalah permainan ini mengajarkan untuk saling percaya satu sama lain dengan teman kelompoknya. Hal ini dapat dilihat pada indikator kecerdasan interpersonal, yaitu mampu mempengaruhi pendapat dan tindakan teman serta keahlian untuk berkerja dalam kelompok. Pada kegiatan bisik berantai, siswa dapat dirangsang kecerdasan interpersonalnya untuk percaya mengenai pesan yang disampaikan oleh teman sekelompok. Kepercayaan ini penting bagi proses pembelajaran, ketika individu saling percaya, maka kualitas pembelajaran semakin baik, karena adanya ikatan batin baik antar siswa sendiri, maupun antara guru ke siswa. 
Hasil penelitian didapatkan bahwa setiap siswa di kelas $1 \mathrm{D}$ diajarkan oleh wali kelasnya untuk saling percaya kepada temannya. khususnya dalam konteks ini adalah percaya dengan teman satu kelompok, karena dalam kecerdasan interpersonal siswa yang menyampaikan dengan kepercayaan teman yang mendengarnya akan membuat siswa tersebut lebih percaya diri dengan apa yang disampaikannya. Dengan demikian, seiring berjalannya waktu, maka siswa terlatih untuk berpendapat dan mempengaruhi tindakan teman sebayanya serta menjadi penengah dalam setiap problem yang dihadapinya. Dengan permainan tersebut, siswa juga terlatih memiliki keahlian untuk bekerja dalam kelompok dengan baik, sehingga ia dapat dijadikan 'ruang curhat' teman-teman lainnya. Dari pemahaman ini akan berpengaruh positif terhadap kecerdasan interpersonal diri siswa ke depan.

\section{Mengenali berbagai cara untuk berhubungan dan peka terhadap perasaan, motivasi, dan keadaan mental seseorang}

Dalam indikator ini, dapat dipahami adalah bagaimana perasaan empati siswa dapat dilihat. Dalam pembentukkannya, model pembelajaran menyimak tipe bisik berantai ini, guru mengkomunikasikan kepada siswa agar saling menghargai antar teman serta antar kelompok, karena dalam setiap permainan selalu terdapat kekalahan dan kemenangan.

Dalam permainan ini, kemenangan dan kekalahan dari setiap kelompok siswa tidak menjadi hal pokok, karena tujuan permainan ini adalah untuk menstimulus kecerdasan interpersonal siswa. Semakin siswa memiliki kecerdasan interpersonal, maka semakin siswa tersebut mampu bersosial dengan lingkungannya secara baik. Hal ini telah ditekankan oleh guru di kelas 1 D MI Al Hamid Banjarmasin.

\section{Membentuk dan mempertahankan hubungan sosial}

Hal yang terlihat dari indikator ini adalah siswa merasa senang berinteraksi dan memiliki banyak teman, selalu bergembira dan membuat teman gembira, dan suka kegiatan berkelompok. Berdasarkan hasil penelitian, model pembelajaran menyimak tipe berantai ini membuat siswa dapat saling bekerjasama dengan teman kelompoknya dan dapat membentuk serta mempertahankan hubungan sosial. Berdasarkan hasil wawancara kepada setiap perwakilan kelompok, rata-rata dari mereka merasa senang dan lebih suka berkegiatan yang bersifat kelompok.

Hal ini sesuai dengan penjelasan Faridah Kartono dan Siti Halidjah bahwa kelebihan dari model pembelajaran menyimak tipe bisik berantai yaitu dapat meningkatkan keaktifan siswa dalam proses belajar mengajar, melatih empat keterampilan bahasa, menarik minat siswa dalam pembelajaran, menimbulkan rasa bahagia, tanpa beban dalam proses belajar mengajar dan meningkatkan rasa kerja sama antarsiswa (Kartono, 2013:9).

\section{Mudah bergaul dan beradaptasi dengan baik}

Indikator ini dapat dipahami bahwa anak senang berada dalam tempat yang berisi banyak orang, senang berkenalan dengan teman baru, dan tidak merasa sungkan untuk memulai suatu obrolan dengan orang di sekitar. Hal ini karena implementasi model pembelajaran menyimak tipe bisik berantai ini mengharuskan agar kegiatan pembelajaran dilakukan secara berkelompok, sehingga satu anak dengan yang lain harus bergaul dan beradaptasi satu sama lainnya.

Hasil implementasi di lapangan, dari 29 siswa dibagi menjadi lima kelompok, artinya dalam satu kelompok terdiri dari 5-6 siswa yang memiliki karakter yang berbeda. Dalam kasus tertentu dan untuk menyamaratakan, guru membagi kelompok secara acak. Ada karakter anak 
yang pasif dan anak yang aktif di dalam satu kelompok. Kebijakan guru tersebut akan berdampak kepada penyataraan kemampuan siswa, karena setiap kerjasama kelompok akan saling membantu atau menyempurnakan segala kekurangan dari kelompoknya masing-masing. Maka dari itu, siswa yang aktif secara tidak langsung menularkan kemampuannya kepada siswa yang pasif, sehingga siswa yang pasif 'dipaksa' untuk aktif dalam sebuah permainan kelompok. Tentu hal ini akan berdampak positif terhadap jalannya proses pembelajaran secara umum.

\section{Kesimpulan}

Implementasi model pembelajaran menyimak tipe bisik berantai yang dilakukan guru kelas 1D Ml Al Hamid Banjarmasin telah berjalan dengan baik sesuai langkah-langkah yang ada. Guru kelas tersebut juga menambahkan beberapa variasi mengajar untuk menunjang pembelajaran agar efektif dan tepat sasaran. Kecerdasan interpersonal yang dapat didiskripsikan peneliti berdasarkan hasil di lapangan dan sesuai indikator yang ada adalah siswa mampu berkomunikasi dengan baik secar aktif. Hal ini diperkuatnya adanya pengkodean dari guru sehingga proses pembelajaran berjalan kondusif. Dengan permainan bisik berantai ini, siswa lebih tertanam rasa percaya diri dan memiliki jiwa sosial yang baik. Hal ini dibuktikan siswa yang pasif selama di kelas, melalui permainan ini mereka dituntut untuk aktif dan beradaptasi dengan siswa yang lainnya. Maka dari itu, proses pembelajaran tipe bisik berantai ini sangat berguna untuk menstimulus dan meningkatkan kecerdasan interpersonal siswa, sehingga ke depan siswa akan peka dan memiliki kepribadian sosial yang baik di lingkungan sekitarnya.

\section{Referensi}

Armstrong, T. (2014). Menerapkan Multiple Intelligences di Sekolah. Virginia: ASCD.

Asih. (2016). Strategi Pembelajaran Bahasa Indonesia. Bandung: Pustaka Setia.

Azwar, S. (1996). Pengantar Psikologi Intelegensi. Yogyakarta: Pustaka Pelajar.

Uno, H. B., \& Kuadrat, M. (2010). Mengelola Kecerdasan dalam Pembelajaran. Jakarta: Bumi Aksara.

Gunawan, A. W. (2005). Born To Be Genius. Jakarta: Gramedia Pustaka Utama.

Iskandarwassid \& Sunendar. (2011). Strategi Pembelajaran Bahasa. Bandung: PT Rosda Karya.

Kartono, F. \& Halidjah, S. (2013). Peningkatan Kemampuan Menyimak Menggunakan Teknik

Permainan Berbisik Berantai di Kelas V Sekolah Dasar Negeri 19 Sungai Pinyuh.

Artikel Penelitian. Pontianak: Universitas Tanjung Pura Pontianak.

Kholifatun, W. (2018). Pengaruh Permainan Bisik Berantai Terhadap Keterampilan Menyimak

Siswa Berdasarkan Penjelasan Yang Disampaikan Secara Lisan Pada Siswa Kelas III

SDN Ngletih 1 Kota Kediri. Universitas Nusantara PGRI Kediri. Jurnal Simki-

Pedagogia, 2(8).

Lwin, M. (2008). Cara Mengembangkan Berbagai Komponen Kecerdasan Terjemahan Christine Sujana. Yogyakarta: Indeks.

Sukmadinata, N. S. (2015). Metode Penelitian Pendidikan. Bandung: Remaja Rosdakarya.

Sugiyono. (2017). Metode Penelitian Kualitatif untuk Penelitian yang Bersifat: Eksploratif Interaktif dan Konstruktif. Bandung: Alfabeta.

Suyatno. (2004). Teknik Pembelajaran Bahasa dan Sastra. Surabaya: SIC.

Safaria, T. (2005). Interpersonal Intelligence: Metode Pengembangan Kecerdasan Interpersonal Anak. Yogyakarta: Amara Books. 
Vol. 2, No. 3, September - December 2019

ISSN 2654-6477

Tarigan, D. (2003). Pendidikan Keterampilan Berbahasa. Jakarta: Pusat Penerbitan Universitas Terbuka.

Yaumi, M. (2012). Pembelajaran Berbasis Multiple Intelligences. Jakarta: Dian Rakyat. 